artelogie

\title{
Artelogie
}

Recherche sur les arts, le patrimoine et la littérature de l'Amérique latine

$7 \mid 2015$

Photographie contemporaine en Amérique latine

\section{Fotografía en América Latina Contemporánea}

\section{Charles Monteiro y Gonzalo Leiva Quijada}

\section{(2) OpenEdition \\ Journals}

\section{Edición electrónica}

URL: https://journals.openedition.org/artelogie/1432

DOI: 10.4000/artelogie.1432

ISSN: 2115-6395

Traducción(es):

Photographie contemporaine en Amérique latine - URL : https://journals.openedition.org/artelogie/ 1057 [fr]

Fotografia na América Latina Contemporânea - URL : https://journals.openedition.org/artelogie/1059 [pt]

Editor

Association ESCAL

Referencia electrónica

Charles Monteiro y Gonzalo Leiva Quijada, «Fotografía en América Latina Contemporánea», Artelogie [En línea], 7 | 2015, Publicado el 15 abril 2015, consultado el 11 abril 2022. URL: http:// journals.openedition.org/artelogie/1432 ; DOI: https://doi.org/10.4000/artelogie.1432

Este documento fue generado automáticamente el 11 abril 2022.

Association ESCAL 


\title{
Fotografía en América Latina Contemporánea
}

\author{
Charles Monteiro y Gonzalo Leiva Quijada
}

1 El dossier sobre fotografía en América Latina Contemporánea tiene tres ejes que constituyen cruces para redefinir la fotografía regional latinoamericana, como centro operacional de asimilación y originalidad creativa. La consideración transdiciplinar, es una linealidad epistemológica que emerge desde un territorio geográfico y mental, asi como desde sistemas representacionales mestizos que por la fotografía desde, por y en Latinoamérica, construye y proyecta con gran vitalidad y heterogeneidad. El dossier reúne un conjunto de 14 artículos

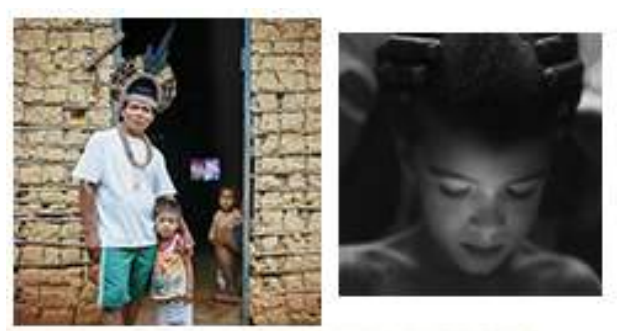
que apuntan a la riqueza y multiplicidad

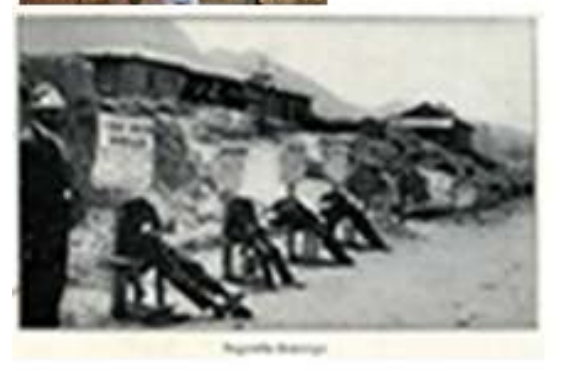
de investigaciones actuales sobre la fotografía en cuanto a temas, enfoques, perspectivas teóricas, así como en términos de geografía (Argentina, Brasil, Chile, Colombia, México, Uruguay, Venezuela) y de un arco de tiempo que va desde la segunda mitad del siglo XIX hasta principios del siglo XXI. Los artículos proponen contribuciones teóricas y metodológicas interdisciplinarias sobre la fotografía en diálogo con los campos de los Estudios Visuales, Historia del Arte, Estética, Historia y Antropología. El cuerpo, el paisaje, las identidades, las distintas miradas sobre las poblaciones autóctonas, los conflictos políticos en la elaboración de imaginarios nacionales y la construcción de imágenes del poder son temas que recorren este número.

2 Los autores respondieron plenamente al desafío lanzado por los organizadores sobre la mirada y la visión como construcciones artísticas, científicas, culturales, políticas y 
sociales en el tiempo. Así también reflexionaron sobre los circuitos de producción, circulación y usos sociales de las imágenes fotográficas, con el objetivo de entender la construcción imaginaria de representaciones y significados sociales en disputa. Ahora bien, el conjunto de artículos se organiza en tres líneas principales: Imaginarios y memorias, Estéticas y antropologías, Prácticas e lenguajes fotográficos.

3 En el primer eje, Imaginarios y memorias, hay un conjunto de artículos que reflexionan sobre la construcción de imaginarios políticos y sociales a través de la fotografía. Magdalena Broquetas problematiza la nueva imaginación nacional en disputa con la modernidad a través de la revista ilustrada "Mundo Uruguayo" de amplia circulación a principios del siglo XX. Carlos Alberto Sampaio Barbosa problematiza la relación fotografía y compromiso político a través de las tensiones que provoca "Frente a Frente" a las revistas mexicanas entre propuestas que unifican discursos de cultura proletaria, realismo socialista y vanguardia artística. Alberto del Castillo Troncoso analiza la narrativa construida por la prensa y los reporteros gráficos en el momento de la masacre de la población civil (estudiantes) en la Plaza de Las Tres Culturas de Tlatelolco, el 2 de octubre de 1968. Juanita Solano Roa muestra cómo la fotografía ayudó a legitimar la persecución y la eliminación de los líderes que se oponían al gobierno del Presidente Rafael Reyes en Colombia, en la secuencia del atentado de 10 de febrero de 1907. Gonzalo Leiva investigó la historia de la fotografía chilena a partir de dos ejes de representación historicistas que caracterizan líneas de producción vivificantes hasta el día de hoy: el paisaje y el cuerpo. Cora Gamarnik problematiza las fotografías publicadas en la prensa, el uso de la violencia y los conflictos políticos en la sociedad post dictadura militar de Argentina a raíz del proceso de apertura previos a las elecciones de 1985.

En el segundo eje Estéticas y antropologías, se analiza el concepto de fotografía e identidades latinoamericanas, así como las diferentes perspectivas sobre las élites, las poblaciones nativas, los afrobrasileños y el proceso de modernización en América Latina. Mathieu Corp discute la categoría "Fotografía latinoamericana", cuya definición es tan problemática como el término de identidad latinoamericana, porque ambos esconden bajo el manto de una supuesta homogeneidad, un conjunto de prácticas sociales muy diferentes y también proyectos fotográficos específicos. Geraldine Guzmán analiza la construcción de una visualidad de la nación a través de un álbum de fotos de Buenos Aires en el contexto de las grandes transformaciones sociales del país entre los años 1880 a 1900. Alejandra Reyero trabaja sobre la fotografía etnográfica de los pueblos indígenas del Chaco en Argentina, produciendo algunos espacios de disidencia, rompiendo con el exotismo y permitiendo la participación activa de los representados en la construcción de su imagen. Ana Bhutto, Dánae Fiore y María José Saletta enfocan la producción de imágenes sobre los toldos tehuelches en la Patagonia, entre Chile y Argentina entre el inicio del siglo XIX hasta principios del siglo XX, cuestionando las miradas diferentes, la permanencia de ciertos objetos y el sesgo de cada forma de representación en dibujos, litografías y fotografías.

5 En el tercer eje Prácticas e lenguajes fotográficos, se centra en los artículos que discuten usos y funciones del retrato en el siglo XIX, las distintas miradas entre la tradición y el arte de los afrobrasileños, las relaciones entre fotoperiodismo y foto documentalista y el diálogo posible entre la fotografía artística y etnográfica. Ana María Mauad reflexiona sobre la edificación de una imagen de la sociedad brasileña a través de una colección de retratos. Alice Heeren analiza el diálogo y al mismo tiempo el 
desprendimiento de la estética fotográfica de Mario Cravo Neto de la tradición de la fotografía documental y etnográfica en Brasil. Charles Monteiro analiza las transformaciones en el campo de la fotografía y su institucionalización en los años 1970 y 1980 a través del compromiso político de los reporteros gráficos por una exigencia más artístico y autoral de la foto documento. Fernanda Aguiar Martins de Castro construye un diálogo entre la antropología y el arte a través del proyecto fotográfico "Translitorânea" de Andrea Eichenberger, sobre la vida de los habitantes de los bordes de la carretera federal brasileña BR 101. Lisa Blackmore discurre sobre la penetración y el uso de imágenes en internet en América Latina a través del estudio de caso sobre la obra de la artista venezolana Erika Ordosgoitti, que realiza intervenciones corporales perfomáticas en espacios públicos. Sus fotografías circulando en Facebook, provocan nuevas perspectivas sobre el cuerpo cuestionando las formas hegemónicas de comunicación y de construcción de la mirada.

6 A través de este dossier pretendemos provocar un debate reflexivo sobre los diferentes usos sociales, identidades, poderes y maneras de ver las sociedades latinoamericanas a través de la fotografía. Alimentamos reconsideraciones sobre el médium fotográfico y sus alcances, proceso iniciado en los años 1970. Ahora bien buscamos poner en tensión los estereotipos y prejuicios fotográficos sobre América Latina con un examen crítico, tratando de establecer directrices y proponiendo la formación de nuevas redes de investigación sobre el tema.

\section{RESÚMENES}

El dossier sobre fotografía en América Latina Contemporánea tiene tres ejes que constituyen cruces para redefinir la fotografía regional latinoamericana, como centro operacional de asimilación y originalidad creativa. La consideración transdiciplinar, es una linealidad epistemológica que emerge desde un territorio geográfico y mental, asi como desde sistemas representacionales mestizos que por la fotografía desde, por y en Latinoamérica, construye y proyecta con gran vitalidad y heterogeneidad.

\section{ÍNDICE}

Palabras claves: fotografía, América Latina, imaginarios, memorias, estéticas, antropologías, prácticas, lenguajes fotográficos

\section{AUTORES \\ CHARLES MONTEIRO}

(PUC-RSBrasil) 


\section{GONZALO LEIVA QUIJADA}

(PUC-Chile) 